\title{
PENYUSUNAN STANDAR PELAYANAN MINIMAL JALAN NASIONAL
}

\author{
Adi Soelistijo \\ Direktorat Jenderal Bina Konstruksi \\ Kementerian Pekerjaan Umum dan Perumahan Rakyat \\ Jln. Pattimura No. 20, Jakarta Selatan \\ soelistijo59@yahoo.co.id
}

\author{
Prayoga Luthfil Hadi \\ Magister Teknik Sipil \\ Universitas Katolik Parahyangan \\ Jln. Ciumbuleuit No. 94, Bandung \\ prayoga.lh@gmail.com
}

\begin{abstract}
Road infrastructure is one component of land transportation and has an important role for the movement of people and goods and regional development. In its implementation, a minimum service standard is needed to ensure the level of service expected road users. In this study, the process of preparing minimum service standards for national roads was discussed. The preparation is carried out through several stages so as to produce a list of indicators and parameters that can be implemented for national roads in Indonesia. The list of indicators and parameters was obtained through collecting data from previous studies, regulations, best practices on the implementation of minimum service standards in other countries, as well as discussions with road operators, academics, and road users. The list of indicators and parameters is then validated by distributing questionnaires back to road operators, academics, and road users to be assessed quantitatively on the level of importance and ease of implementation. Data from respondents were then analyzed using quadrant analysis to obtain priority indicators and parameters proposed to be used in minimum service standards of national roads.
\end{abstract}

Keywords: road infrastructure, national roads, minimum service standards, level of service

\begin{abstract}
Abstrak
Infrastruktur jalan merupakan salah satu komponen dalam penyelenggaraan transportasi darat dan memiliki peranan penting untuk pergerakan orang dan barang serta pengembangan wilayah. Dalam penyelenggaraannya, diperlukan suatu standar pelayanan minimal untuk menjamin tingkat pelayanan yang diharapkan oleh pengguna jalan. Pada kajian ini dibahas proses penyusunan standar pelayanan minimal untuk jalan nasional nontol. Penyusunan dilakukan melalui beberapa tahapan sehingga menghasilkan daftar indikator dan parameter yang dapat diimplementasikan untuk jalan nasional di Indonesia. Daftar indikator dan parameter tersebut diperoleh melalui pengumpulan data dari studi terdahulu, peraturan, best practice penerapan standar pelayanan minimal di negara lain, serta diskusi dengan penyelenggara jalan, akademisi, dan pengguna jalan. Daftar indikator dan parameter tersebut kemudian divalidasi dengan penyebaran kuesioner kembali ke penyelenggara jalan, akademisi, dan pengguna jalan untuk dinilai secara kuantitatif tingkat kepentingan dan kemudahan implementasinya. Data dari responden kemudian dianalisis menggunakan analisis kuadran untuk mendapatkan indikator dan parameter prioritas yang diusulkan untuk digunakan dalam standar pelayan minimal jalan nasional nontol.
\end{abstract}

Kata-kata kunci: infrastruktur jalan, jalan nasional, standar pelayanan minimal, tingkat pelayanan

\section{PENDAHULUAN}

Salah satu pendukung utama lancarnya pergerakan barang dan orang di Indonesia adalah tersedianya transportasi darat yang baik. Tidak dapat dipungkiri bahwa motorisasi di Indonesia, terutama mobil, sepeda motor, dan truk logistik merupakan katalis dalam pergerakan orang dan barang. Infrastruktur jalan juga merupakan prasarana transportasi darat yang memiliki peranan penting dalam perkembangan wilayah. Menurut Undang-Undang Nomor 38 Tahun 2004 tentang Jalan, jalan mempunyai peranan penting dalam mendukung bidang- 
bidang ekonomi, sosial, budaya, dan lingkungan, serta dikembangkan melalui pendekatan pengembangan wilayah agar tercapai keseimbangan dan pemerataan pembangunan antardaerah dalam rangka mewujudkan sasaran pembangunan nasional.

Dilihat dari aspek kualitas, kemantapan jalan nasional terus meningkat setiap tahunnya. Salah satu upaya yang dilakukan oleh pemerintah adalah menyediakan anggaran penanganan jalan, baik untuk pembangunan jalan maupun preservasi terhadap jaringan jalan yang telah ada, melalui pemeliharaan rutin, pemeliharaan berkala, peningkatan, dan rekonstruksi. Agar hal ini dapat dipenuhi, pemerintah memiliki hak dan kewajiban menyelenggarakan jalan melalui kegiatan-kegiatan yang mencakup pengaturan, pembinaan, pembangunan, serta pengawasan terhadap program-program penanganan jalan.

Program penanganan jalan harus merujuk kepada standar, pedoman, dan manual pelaksanaan konstruksi jalan dan kelengkapannya. Dalam Undang-Undang Nomor 38 Tahun 2004 tentang Jalan, disebutkan bahwa penyelenggara jalan wajib memprioritaskan pemeliharaan, perawatan, dan pemeriksaan jalan secara berkala untuk mempertahankan tingkat pelayanan jalan sesuai dengan Standar Pelayanan Minimal (SPM) yang ditetapkan. Hal ini diperkuat oleh Peraturan Pemerintah Nomor 34 Tahun 2006 tentang Jalan, yang menyatakan bahwa pelayanan jalan umum ditentukan dengan kriteria yang dituangkan dalam standar pelayanan minimal yang terdiri atas standar pelayanan minimal jaringan jalan dan standar pelayanan minimal ruas jalan. Atas dasar tersebut, perlu dikaji penyiapan standar pelayanan minimal untuk jalan umum nontol yang terukur dan dapat diimplementasikan.

Penyelenggaraan negara dan pemerintahan yang baik tidak pernah terlepas dari besaran pelayanan yang diberikan kepada warganya. OPM dan CIPFA (2004) menyatakan bahwa pemerintah harus mempunyai target dan tujuan dalam kegiatan pemerintahannya. Untuk itu, diperlukan suatu target yang terukur untuk menjamin pemenuhan pelayanan yang dibutuhkan warga negara. Target ini harus secara jelas menggambarkan tingkat pelayanan minimal yang harus dipenuhi oleh pemerintah dan pembagian tanggung jawab pemenuhannya.

Amanat tentang adanya standar pelayanan minimal untuk jalan umum di Indonesia sudah sering dibahas. Dalam UU No. 38 Tahun 2004 tentang Jalan, PP No. 34 Tahun 2006 tentang Jalan, dan Permen PU No. 14/PRT/M/2010 tentang Standar Pelayanan Minimal Bidang Pekerjaan Umum dan Penataan Ruang disyaratkan adanya suatu standar pelayanan minimal untuk pelayanan umum dasar, terutama dalam bidang pekerjaan umum dan penataan ruang. Iskandar (2011) mendefinisikan SPM Jalan sebagai suatu ukuran teknik fisik jalan yang sesuai dengan kriteria teknis yang ditetapkan, dan harus dicapai oleh setiap jaringan jalan dan ruas-ruas jalan yang ada dalam kurun waktu yang ditentukan.

SPM mulai dikenal luas oleh publik di Indonesia pada tahun 2005 melalui Peraturan Pemerintah No. 65 Tahun 2005, tentang Pedoman Penyusunan dan Penerapan Standar Pelayanan Minimal. SPM ini dijelaskan sebagai ketentuan tentang jenis dan mutu pelayanan dasar yang merupakan urusan wajib daerah yang berhak diperoleh setiap warga negara secara minimal. Dalam SPM ini terdapat indikator SPM yang didefinisikan sebagai tolok ukur prestasi kuantitatif dan kualitatif (measureable) yang digunakan untuk menggambarkan besaran sasaran yang hendak dipenuhi dalam pencapaian suatu SPM tertentu, berupa masukan, proses, hasil dan/atau manfaat pelayanan, serta dapat dicapai (achievable). 
UU Nomor 38 Tahun 2004 menyatakan bahwa indikator yang harus diperhatikan dalam SPM Jalan Umum harus meliputi aspek aksesibilitas (kemudahan pencapaian), mobilitas, kondisi jalan, keselamatan, dan kecepatan tempuh rata-rata. Seiring dengan UU Nomor 38 Tahun 2004, dalam PP Nomor 34 Tahun 2006 dinyatakan bahwa SPM jaringan jalan harus meliputi aksesibilitas, mobilitas, dan keselamatan serta SPM ruas jalan harus meliputi kondisi jalan dan kecepatan.

Studi mengenai Penyusunan Standar Pelayanan Jalan Nasional Nontol ini dilakukan dengan beberapa tahapan. Tahap pertama adalah studi literatur, peraturan atau kebijakan terkait, dan best practice di negara lain untuk menentukan kebutuhan daftar panjang indikator dan nilai pemenuhan indikator dalam SPM Jalan Nasional. Daftar panjang ini dibagi menjadi Indikator Fungsional Ruas Jalan, Indikator Struktural Ruas Jalan, Indikator Keselamatan Ruas Jalan, Indikator Jaringan Jalan, dan Indikator Lain. Pengertian indikator fungsional merupakan karakteristik perkerasan jalan yang secara langsung memengaruhi keselamatan dan kenyamanan pengguna jalan serta pelayanan jalan. Indikator struktural merupakan kinerja struktur perkerasan terhadap beban lalu lintas dan kondisi lingkungan. Indikator keselamatan adalah kondisi fisik dan aksesoris jalan yang harus dimiliki untuk membantu pengguna jalan menggunakan fasilitas jalan dengan aman dan selamat. Indikator jaringan adalah kondisi keterpaduan beberapa ruas jalan dalam melayani kebutuhan lalu lintas.

Daftar panjang tersebut kemudian disusun dalam suatu kuesioner yang ditanyakan kepada berbagai narasumber, baik dari kalangan penyelenggara jalan (Direktorat Jenderal Bina Marga, Kementerian Pekerjaan Umum dan Perumahan Rakyat), akademisi, dan pengguna jalan. Hasil dari kuesioner ini kemudian dianalisis untuk mendapatkan daftar pendek indikator dan nilai pemenuhan indikator SPM Jalan Nasional. Daftar pendek ini kemudian dibahas dengan mengundang berbagai pemangku kepentingan (stakeholders) untuk difinalisasi sebagai Usulan Standar Pelayanan Minimal Jalan Nasional Nontol.

\section{PENYUSUNAN DAFTAR PANJANG INDIKATOR}

Daftar panjang indikator disusun berdasarkan berbagai regulasi yang berlaku di Indonesia dan penerapan standar pelayanan minimal di negara lain. Regulasi dan standar Indonesia yang dijadikan acuan dalam penyusunan daftar panjang indikator adalah dokumen SPM Jalan Daerah melalui Permen PU Nomor 11 Tahun 2010 tentang Tata Cara dan Persyaratan Laik Fungsi Jalan (Kementerian PU, 2010a), Permen PU Nomor 14 Tahun 2010 tentang SPM Bidang Pekerjaan Umum dan Penataan Ruang (Kementerian PU, 2010b), Persyaratan Teknis Jalan dan Kriteria Perencanaan Teknis Jalan (Kementerian PU, 2011), Permenhub Nomor 13 Tahun 2014 tentang Rambu Lalu Lintas (Kementerian Perhubungan, 2014b), Permenhub Nomor 34 Tahun 2014 tentang Marka Jalan (Kementerian Perhubungan, 2014a), dan SPM Jalan Tol (Kementerian PU, 2014). Sedangkan best practice yang digunakan dalam penyusunan daftar panjang indikator adalah beberapa SPM Jalan Nasional di China, Kazakhstan, Mongolia, dan Korea Selatan (UNESCAP, 2003), SPM Jalan Negara 
India (Planning Commission Government of India, 2010), dan Manual of Uniform Minimum Standards for Design, Construction and Maintenance for Streets and Highways (Florida Department of Transportation, 2013).

Daftar panjang indikator yang didapat untuk Indikator Fungsional Ruas adalah: 1) kekesatan; 2) kerataan; 3) kelandaian maksimal; 4) lebar median; 5) lebar lajur; 6) lebar bahu; 7) lebar badan jalan; dan 8) lebar ROW. Sedangkan daftar panjang Indikator Struktural adalah: 1) tebal perkerasan; 2) lebar tanah dasar; 3) kedalaman alur; 4) intensitas alur; 5) lebar retak; 6) intensitas retak; 7) kedalaman lubang; 8) intensitas lubang; 9) tekstur permukaan jalan; 10) aspal yang meleleh; 11) jenis perkerasan; 12) kekuatan konstruksi; 13) drainase permukaan perkerasan jalan; dan 14) bahan perkerasan. Sementara itu, daftar panjang Indikator Keselamatan adalah: 1) kecepatan rencana; 2) alinyemen horizontal; 3) alinyemen vertikal; 4) jarak pandang; 5) jarak pandang henti; 6) height clearance; 7) perambuan; 8) jenis rambu; 9) penempatan rambu; 10) marka jalan; 11) marka persimpangan; 12) zebra cross; 13) guide post (reflector); 14) penerangan jalan umum; 15) anti silau; 16) kerb; 17) median concrete barrier; 18) guard rail; 19) wire rope; 20) pulau jalan; 21) bentuk pulau jalan; 22) trotoar; 23) perkerasan dan kondisi trotoar; 24) pemanfaatan oleh selain pejalan kaki; 25) utilitas pada trotoar; 26) APILL; 27) pengaturan fase; 28) fase khusus penyeberang; 29) fasilitas penyandang cacat; dan 30) fasilitas penyeberangan.

\section{PENYUSUNAN DAFTAR PENDEK INDIKATOR DAN PENILAIAN INDIKATOR PENTING}

Indikator yang didapat dari daftar panjang kemudian ditanyakan dalam bentuk kuesioner ke berbagai pemangku kepentingan dari kalangan penyelenggara jalan dan akademisi. Berdasarkan masukan dari berbagai pemangku kepentingan, diperoleh daftar pendek indikator yang dirasa cocok dan dapat diimplementasikan di Indonesia. Indikator-indikator tersebut kemudian disusun dalam suatu kuesioner yang ditanyakan kepada penyelenggara jalan, akademisi, dan pengguna jalan. Bentuk kuesioner ini ditunjukkan pada Tabel 1.

Kuesioner tersebut ditanyakan kepada berbagai stakeholder yang ada, baik sebagai penyelenggara jalan, akademisi, maupun pengguna jalan. Responden yang berpartisipasi dalam kegiatan ini sebanyak 52 responden, dengan proporsi 35 orang penyelenggara jalan dan 17 orang akademisi dan pengguna jalan. Responden ditanyakan mengenai tingkat kepentingan dan kemudahan implementasi bagi masing-masing indikator.

\section{ANALISIS DATA UNTUK PENYUSUNAN INDIKATOR SPM JALAN NASIONAL NONTOL}

Data dari responden kemudian dianalisis dengan menggunakan analisis kuadran. Analisis ini dilakukan untuk mengklasifikasi tingkat kepentingan dan kemudahan dari 
masing-masing indikator yang kemudian akan ditetapkan sebagai indikator SPM Jalan Nasional Nontol. Untuk setiap indikator, masing-masing parameter akan diklasifikasi sesuai peringkat "Penting dan Mudah", "Penting dan Sulit", "Tidak Penting dan Mudah", dan "Tidak Penting dan Sulit". Parameter yang dijadikan prioritas untuk dimasukkan ke dalam indikator SPM Jalan Nasional Nontol adalah parameter yang masuk dalam klasifikasi "Penting dan Mudah" dan "Penting dan Sulit".

Tabel 1 Bentuk Kuesioner

\begin{tabular}{|c|c|c|c|c|c|c|c|c|c|}
\hline \multirow{3}{*}{ No. } & \multirow{3}{*}{$\begin{array}{l}\text { Sub-Variabel dan } \\
\text { Indikator }\end{array}$} & \multicolumn{4}{|c|}{ Tingkat Kepentingan } & \multicolumn{4}{|c|}{ Tingkat Kemudahan Implementasi } \\
\hline & & \multicolumn{4}{|c|}{ Tidak Penting Penting } & \multicolumn{4}{|c|}{ Sulit Mudah } \\
\hline & & \multicolumn{4}{|c|}{$\langle------------------------\rangle$} & \multicolumn{4}{|c|}{$\langle-----------------------\rangle$} \\
\hline A. & Indikator Struktural & & & & & & & & \\
\hline 1. & Indikator A & 1 & 2 & 3 & 4 & 1 & 2 & 3 & 4 \\
\hline 2. & Indikator B & 1 & 2 & 3 & 4 & 1 & 2 & 3 & 4 \\
\hline B. & Indikator Fungsional & & & & & & & & \\
\hline 3. & Indikator $\mathrm{C}$ & 1 & 2 & 3 & 4 & 1 & 2 & 3 & 4 \\
\hline 4. & Indikator D & 1 & 2 & 3 & 4 & 1 & 2 & 3 & 4 \\
\hline C. & Indikator Keselamatan & & & & & & & & \\
\hline 5. & Indikator E & 1 & 2 & 3 & 4 & 1 & 2 & 3 & 4 \\
\hline 6. & Indikator F & 1 & 2 & 3 & 4 & 1 & 2 & 3 & 4 \\
\hline
\end{tabular}

\section{Analisis Kuadran Indikator Jaringan}

Tabel 2 dan Gambar 1 menunjukkan hasil analisis kuadran untuk indikator jaringan. Hasil yang didapat menunjukkan bahwa parameter "rasio panjang jalan mantap terhadap jaringan" dan "keselamatan" masuk dalam kelompok "Penting dan Mudah”. Sedangkan parameter "jumlah lajur" dan "derajat kejenuhan" masuk dalam kelompok "Penting dan Sulit".

Tabel 2 Klasifikasi Kuadran Indikator Jaringan

\begin{tabular}{l|l|c}
\hline \multicolumn{1}{c|}{ Kuadran } & \multicolumn{1}{|c}{ Indikator Jaringan } & Kode \\
\hline Penting dan Mudah & Rasio panjang jalan mantap terhadap jaringan & A3 \\
& Keselamatan & A6 \\
Penting dan Sulit & Jumlah lajur & A1 \\
& Derajat kejenuhan & A2 \\
Tidak Penting dan Mudah & Akses per km & A4 \\
Tidak Penting dan Sulit & Rasio jalan terhadap luas wilayah & A5 \\
\hline
\end{tabular}

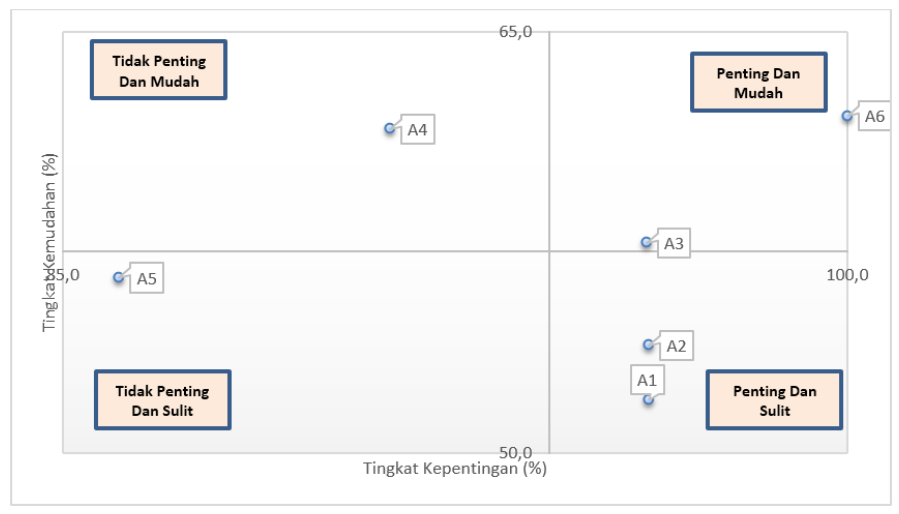

Gambar 1 Analisis Kuadran Tingkat Kepentingan dan Kemudahan Indikator Jaringan 


\section{Analisis Kuadran Indikator Fungsional}

Gambar 2, Gambar 3, Tabel 3, dan Tabel 4 menunjukkan hasil analisis kuadran untuk indikator fungsional. Hasil yang didapat menunjukkan bahwa parameter "kekesatan" dan "lebar median" merupakan parameter yang dianggap "Tidak Penting dan Mudah", baik untuk perkerasan kaku maupun perkerasan lentur.

Jika pada perkerasan lentur, parameter yang masuk kategori "Penting dan Mudah" adalah kerataan dan kelandaian maksimal, maka untuk perkerasan kaku, parameter yang masuk kategori "Penting dan Mudah" adalah kerataan dan lebar lajur. Hal ini menunjukkan bahwa untuk kedua jenis perkerasan, kerataan merupakan parameter yang krusial untuk ada di dalam SPM menurut responden.

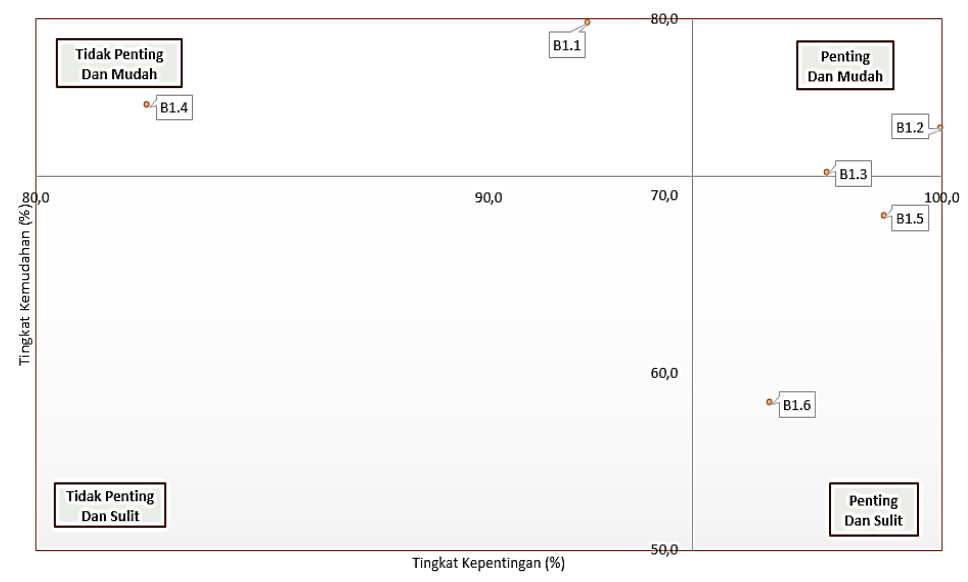

Gambar 2 Analisis Kuadran Tingkat Kepentingan dan Kemudahan Indikator Fungsional Perkerasan Lentur

Tabel 3 Klasifikasi Kuadran Indikator Fungsional Perkerasan Lentur

\begin{tabular}{l|l|c}
\hline \multicolumn{1}{c|}{ Kuadran } & Indikator Fungsional (Perkerasan Lentur) & Kode \\
\hline Penting dan Mudah & Kerataan & B1.2 \\
& Kelandaian maksimal & B1.3 \\
Penting dan Sulit & Lebar lajur & B1.5 \\
& Lebar bahu & B1.6 \\
Tidak Penting dan Mudah & Kekesatan & B1.1 \\
Tidak Penting dan Sulit & Lebar median & B1.4 \\
\hline
\end{tabular}

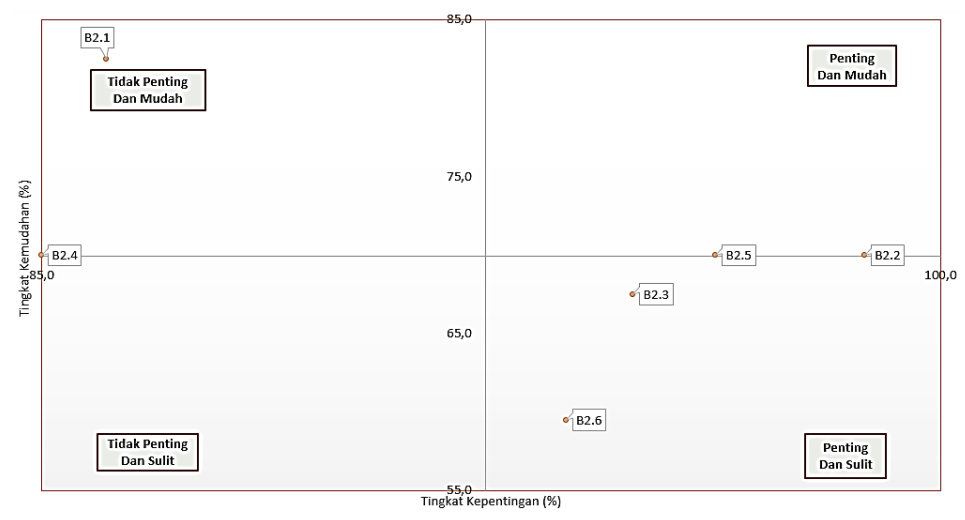

Gambar 3 Analisis Kuadran Tingkat Kepentingan dan Kemudahan Indikator Fungsional Perkerasan Kaku 
Tabel 4 Klasifikasi Kuadran Indikator Fungsional Perkerasan Kaku

\begin{tabular}{l|l|c}
\hline \multicolumn{1}{c|}{ Kuadran } & Indikator Fungsional (Perkerasan Kaku) & Kode \\
\hline Penting dan Mudah & Kerataan & B2.2 \\
& Lebar lajur & B2.5 \\
Penting dan Sulit & Kelandaian maksimal & B2.3 \\
& Lebar bahu & B2.6 \\
Tidak Penting dan Mudah & Kekesatan & B2.1 \\
& Lebar median & B2.4 \\
Tidak Penting dan Sulit & - & - \\
\hline
\end{tabular}

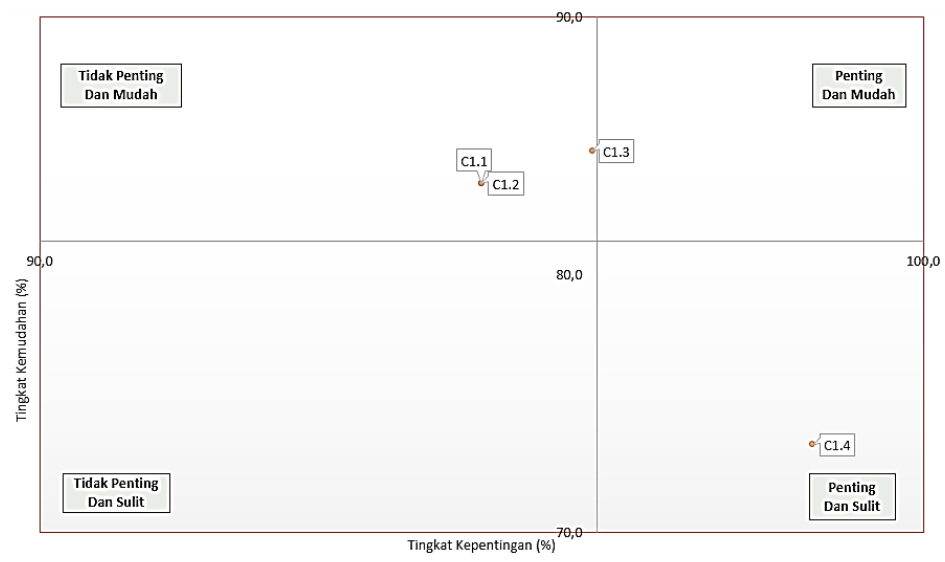

Gambar 4 Analisis Kuadran Tingkat Kepentingan dan Kemudahan Indikator Struktural Perkerasan Lentur

\section{Analisis Kuadran Indikator Struktural}

Hasil analisis kuadran indikator struktural untuk perkerasan lentur menunjukkan bahwa tidak ada parameter yang masuk ke dalam kategori "Penting dan Mudah". Dari 4 parameter, sebanyak 3 di antaranya masuk ke dalam kategori "Tidak Penting dan Mudah", sedangkan parameter "drainase permukaan perkerasan jalan" masuk dalam kategori "Penting dan Sulit".

Tabel 5 Klasifikasi Kuadran Indikator Struktural Perkerasan Lentur

\begin{tabular}{l|l|c}
\hline \multicolumn{1}{c|}{ Kuadran } & \multicolumn{1}{|c}{ Indikator Struktural (Perkerasan Lentur) } & Kode \\
\hline Penting dan Mudah & - & - \\
Penting dan Sulit & Drainase permukaan perkerasan jalan & $\mathrm{C} 1.4$ \\
& Alur & $\mathrm{C} 1.1$ \\
Tidak Penting dan Mudah & Retak & $\mathrm{C} 1.2$ \\
& Lubang & $\mathrm{C} 1.3$ \\
Tidak Penting dan Sulit & - & - \\
\hline
\end{tabular}

Pada perkerasan kaku, parameter yang masuk ke dalam kategori "Penting dan Mudah" adalah parameter "retak" dan "drainase permukaan perkerasan jalan". Parameter "alur" dan "lubang" masuk ke dalam kategori "Tidak Penting dan Sulit". Tidak ada parameter yang masuk ke dalam kategori "Penting dan Sulit" dan "Tidak Penting dan Mudah".

\section{Analisis Kuadran Indikator Keselamatan}

Untuk indikator keselamatan, berdasarkan hasil analisis kuadran, parameter yang masuk ke dalam kategori "Penting dan Mudah" antara lain: "Kelandaian”, "Perambuan", 
“Marka Jalan”, “Guard Rail”, dan "Penerangan Jalan”. Parameter-parameter yang masuk kategori "Penting dan Sulit”, antara lain: "Kecepatan Rencana”, "Radius Tikungan”, "Superelevasi", "Crown", "Jarak Pandang Henti", dan "Height Clearance".

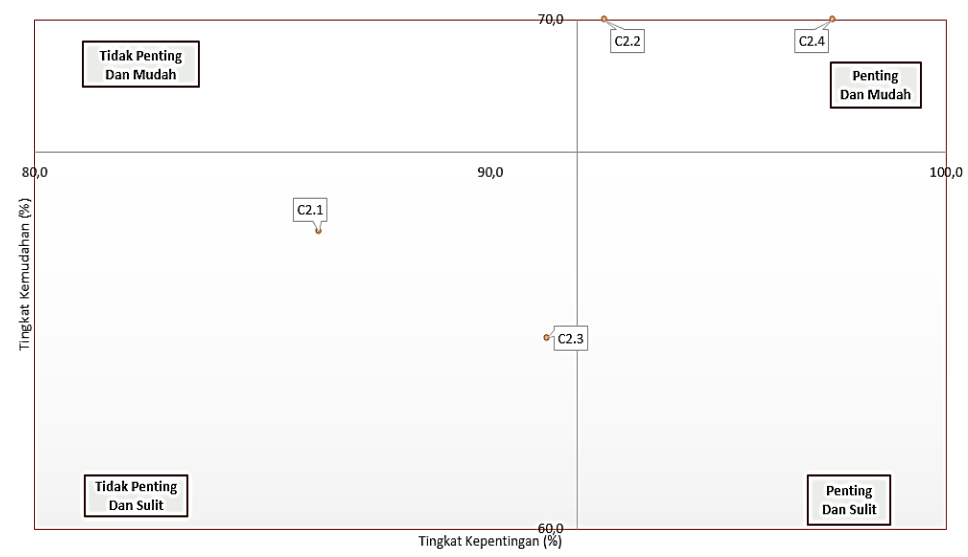

Gambar 5 Analisis Kuadran Tingkat Kepentingan dan Kemudahan Indikator Struktural Perkerasan Kaku

Tabel 6 Klasifikasi Kuadran Indikator Struktural Perkerasan Kaku

\begin{tabular}{l|l|c}
\hline \multicolumn{1}{c|}{ Kuadran } & \multicolumn{1}{|c}{ Indikator Struktural (Perkerasan Kaku) } & Kode \\
\hline Penting dan Mudah & Retak & C2.2 \\
& Drainase permukaan perkerasan jalan & C2.4 \\
Penting dan Sulit & - & - \\
Tidak Penting dan Mudah & - & - \\
Tidak Penting dan Sulit & Alur & C2.1 \\
& Lubang & C2.3 \\
\hline
\end{tabular}

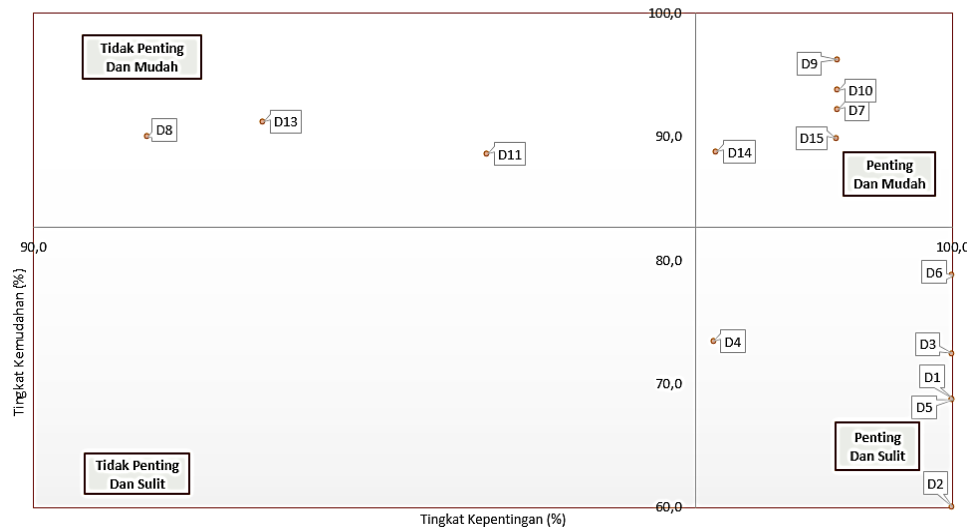

Gambar 6 Analisis Kuadran Tingkat Kepentingan dan Kemudahan Indikator Keselamatan

\section{Analisis Kuadran Indikator Tambahan}

Hasil analisis kuadran untuk indikator tambahan menunjukkan bahwa hanya 1 parameter yang masuk ke dalam kategori "Penting dan Mudah", yaitu "Patok Kilometer". Parameter "Lebar Rumaja", "Pemanfaatan Rumaja", "Lebar Rumija", "Pemanfaatan Rumija", "Lebar Ruwasja", dan "Drainase" masuk ke dalam kategori "Penting dan Sulit". 
Tabel 7 Klasifikasi Kuadran Indikator Keselamatan

\begin{tabular}{c|l|c}
\hline \multicolumn{1}{c|}{ Kuadran } & \multicolumn{1}{|c}{ Indikator Keselamatan } & Kode \\
\hline Penting dan Mudah & Kelandaian & D7 \\
& Perambuan & D9 \\
& Marka jalan & D10 \\
& Guard rail & D14 \\
& Penerangan jalan & D15 \\
Penting dan Sulit & Kecepatan rencana & D1 \\
& Radius tikungan & D2 \\
& Superelevasi & D3 \\
& Crown & D4 \\
Tidak Penting dan Mudah & Jarak pandang henti & D5 \\
& Height clearance & D6 \\
& Guide post/reflektor & D8 \\
Tidak Penting dan Sulit & Anti silau & D11 \\
& Kerb & D12 \\
& - & D13 \\
\hline
\end{tabular}

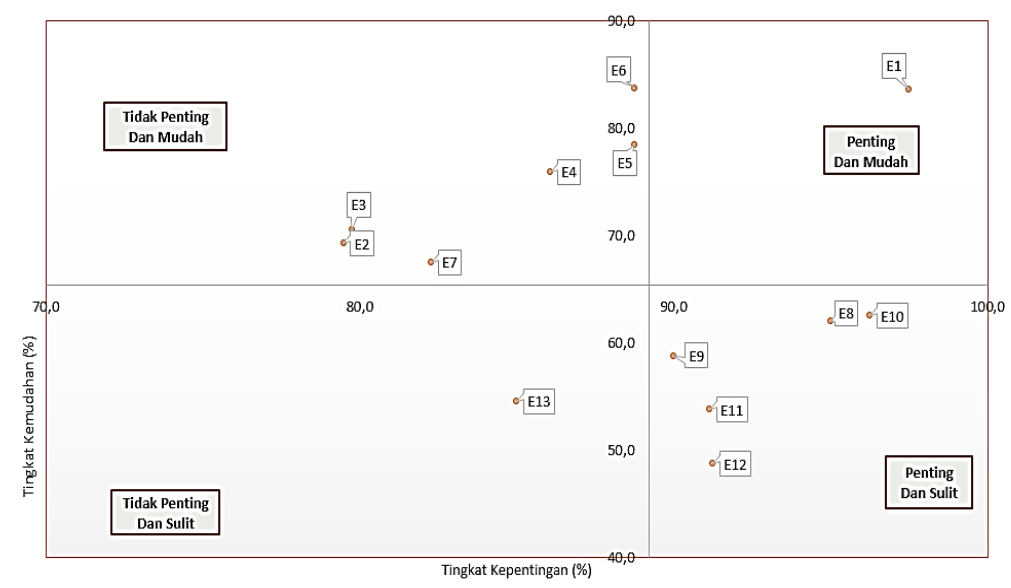

Gambar 7 Analisis Kuadran Tingkat Kepentingan dan Kemudahan Indikator Tambahan

Tabel 8 Klasifikasi Kuadran Indikator Tambahan

\begin{tabular}{l|l|l}
\hline \multicolumn{1}{c|}{ Kuadran } & \multicolumn{1}{|c}{ Indikator Lain } & Kode \\
\hline Penting dan Mudah & Patok kilometer & E1 \\
Penting dan Sulit & Lebar rumaja & E8 \\
& Pemanfaatan rumaja & E9 \\
& Lebar rumija & E10 \\
& Eemanfaatan rumija & E12 \\
& Lebar ruwasja & E14 \\
& Drainase & E2 \\
Tidak Penting dan Mudah & Patok hektometer & E3 \\
& Pagar rumija & E4 \\
& Pagar pengaman & E5 \\
& Kebersihan & E6 \\
Tidak Penting dan Sulit & Pepohonan & E7 \\
\hline
\end{tabular}




\section{USULAN INDIKATOR SPM JALAN NASIONAL NONTOL}

Beberapa parameter yang berdasarkan hasil analisis berada dalam kategori "Tidak Penting dan Mudah" maupun "Tidak Penting dan Sulit” tetap digunakan dalam Usulan SPM Jalan Nasional, karena berdasarkan pengalaman penyelenggara jalan di lapangan, parameterparameter tersebut harus ada. Parameter-parameter yang dimaksud adalah kekesatan, drainase, rasio panjang jalan terhadap luas wilayah, dan akses per kilometer.

Pada Tabel 9 dan Tabel 10 juga dapat dilihat usulan kriteria untuk parameter SPM Jalan Nasional Nontol yang dirangkum atau dikutip dari hasil analisis, berbagai standar acuan, serta studi-studi literatur. Kriteria nilai untuk masing-masing parameter ditentukan berdasarkan hasil analisis, telaah peraturan-peraturan yang ada, dan berdasarkan pengalaman penyelenggara jalan di setiap wilayah.

SPM Ruas Jalan Nasional Nontol terdiri atas indikator fungsional, struktural, tambahan, dan keselamatan. Sedangkan SPM Jaringan Jalan Nasional Nontol terdiri atas indikator aksesibilitas, mobilitas, dan kemantapan jaringan jalan. Indikator-indikator inilah yang diusulkan untuk menjadi SPM Jalan Nasional Nontol di Indonesia.

Tabel 9 Parameter Indikator dan Kriteria Ruas yang Diusulkan Digunakan di SPM Jalan Nasional Nontol

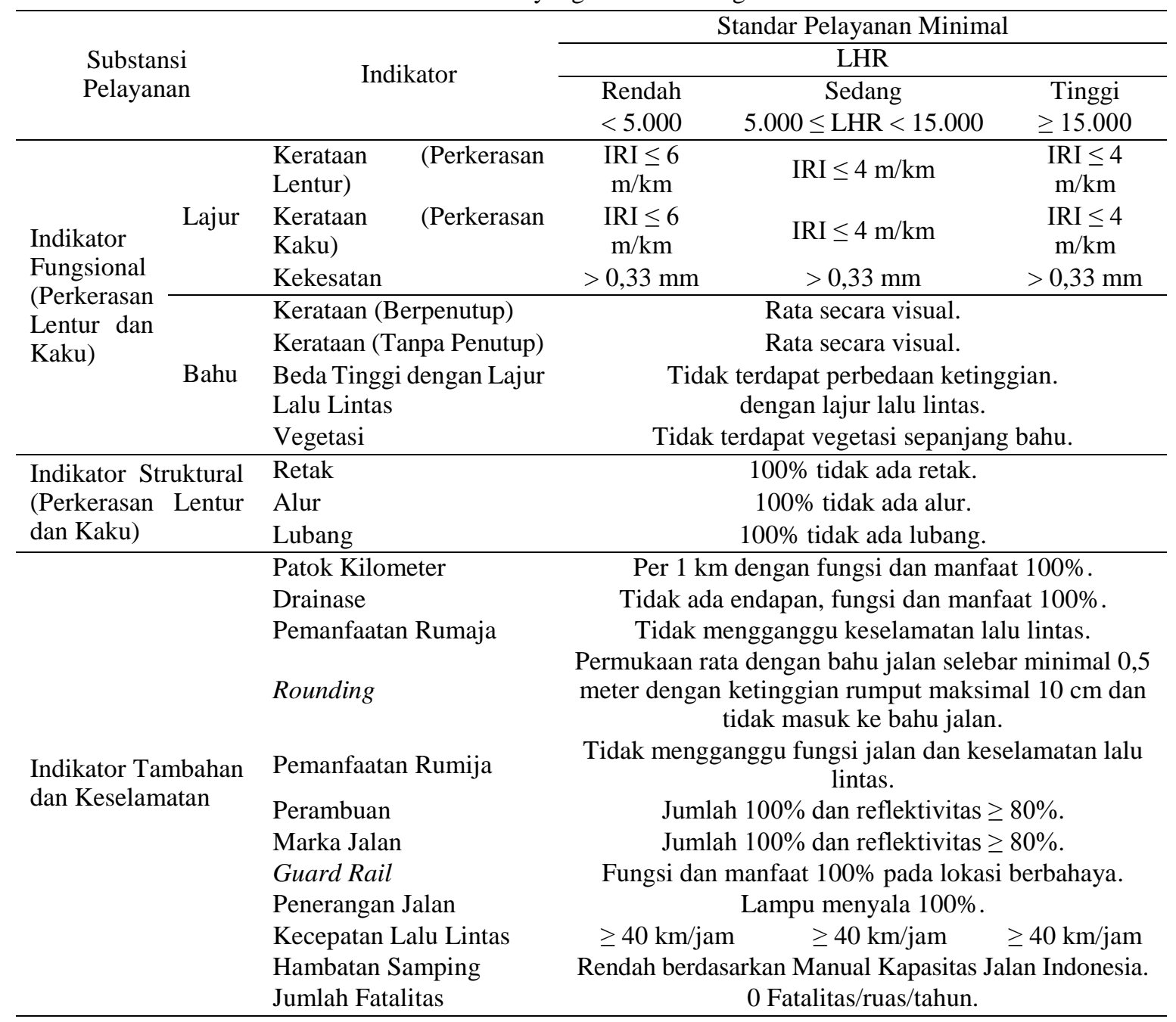


Tabel 10 Parameter Indikator dan Kriteria Jaringan yang Diusulkan Digunakan di SPM Jalan Nasional Nontol

\begin{tabular}{|c|c|c|c|}
\hline \multirow{2}{*}{ Bidang Pelayanan } & \multicolumn{2}{|c|}{ Standar Pelayanan Minimal } & \multirow{2}{*}{ Keterangan } \\
\hline & Kriteria & Nilai & \\
\hline \multirow{4}{*}{ Aksesibilitas } & $\begin{array}{c}\text { Kepadatan Penduduk } \\
\left(\text { jiwa } / \mathrm{km}^{2}\right)\end{array}$ & $\begin{array}{c}\text { Indeks Aksesibilitas } \\
\text { Minimal }\end{array}$ & \multirow{4}{*}{$\begin{array}{c}\text { Panjang } \\
\text { jalan/luas } \\
\left(\mathrm{km} / \mathrm{km}^{2}\right)\end{array}$} \\
\hline & $>800$ & 0,03 & \\
\hline & $60-800$ & 0,02 & \\
\hline & $<60$ & 0,01 & \\
\hline \multirow{4}{*}{ Mobilitas } & $\begin{array}{l}\text { PDRB Per Kapita } \\
\text { (juta Rp/kap/th) }\end{array}$ & Indeks Mobilitas Minimal & \multirow{4}{*}{$\begin{array}{c}\text { Panjang jalan } \\
(\mathrm{km} / 1000 \\
\text { penduduk })\end{array}$} \\
\hline & $>75$ & 0,01 & \\
\hline & $25-75$ & 0,04 & \\
\hline & $<25$ & 0,07 & \\
\hline Kemantapan Jaringan Jalan & Keseluruhan Jaringan & 90 & $\%$ \\
\hline
\end{tabular}

\section{KESIMPULAN}

Berdasarkan tahapan dan proses analisis dalam studi ini, dapat disimpulkan bahwa SPM Jalan Nasional Nontol diperlukan sebagai target pencapaian kinerja penyelenggara jalan nasional nontol. Usulan SPM Jalan Nasional Nontol hasil kajian ini disusun secara terukur (measurable) dan dapat dicapai (achievable), yang terdiri atas Indikator Ruas Jalan Nontol dan Indikator Jaringan Jalan Nasional Nontol.

Indikator Ruas Jalan Nontol terdiri atas parameter fungsional, struktural, tambahan, dan keselamatan. Sedangkan Indikator Jaringan Jalan Nontol terdiri atas parameter aksesibilitas, mobilitas, dan kemantapan jaringan jalan.

Indikator dan Parameter pada Usulan SPM Jalan Nasional Nontol ini diharapkan dapat menjadi acuan penyelenggara jalan nasional nontol. Dengan adanya SPM ini tentunya harapan pengguna jalan nasional dapat terpenuhi.

\section{DAFTAR PUSTAKA}

Florida Department of Transportation. 2013. Florida Greenbook: Manual of Uniform Minimum Standards for Design, Construction and Maintenance for Streets and Highways. Tallahassee, FL.

Iskandar, H. 2011. Kajian Standar Pelayanan Minimal Jalan untuk Jalan Umum Non-Tol. Bandung: Pusat Litbang Jalan dan Jembatan dan Perumahan Rakyat.

Kementerian Pekerjaan Umum. 2010a. Peraturan Menteri PU No. 11/PRT/M/2010 Tahun 2010 tentang Tata Cara dan Persyaratan Laik Fungsi Jalan. Jakarta.

Kementerian Pekerjaan Umum. 2010b. Peraturan Menteri PU No. 14/PRT/M/2010 Tahun 2010 tentang Standar Pelayanan Minimal Bidang Pekerjaan Umum dan Penataan Ruang. Jakarta.

Kementerian Pekerjaan Umum. 2011. Peraturan Menteri PU No. 19/PRT/M/2011 tentang Persyaratan Teknis Jalan dan Kriteria Perencanaan Teknis Jalan. Jakarta. 
Kementerian Pekerjaan Umum. 2014. Peraturan Menteri Pekerjaan Umum Republik Indonesia Nomor 16/PRT/M/2014 tentang Standar Pelayanan Minimal Jalan Tol. Jakarta.

Kementerian Perhubungan. 2014a. Peraturan Menteri Perhubungan Nomor 34 Tahun 2014 tentang Marka Jalan. Jakarta.

Kementerian Perhubungan. 2014b. Peraturan Menteri Perhubungan Nomor 13 Tahun 2014 tentang Rambu Lalu Lintas. Jakarta.

Office for Public Management Ltd. dan The Chartered Institute of Public Finance and Accountancy. 2004. The Good Governance Standard for Public Services. London: Hackney Press Ltd.

Pemerintah Republik Indonesia. 2004. Undang-Undang No. 38 Tahun 2004 tentang Jalan. Jakarta.

Pemerintah Republik Indonesia. 2005. Peraturan Pemerintah No. 65 Tahun 2005 tentang Pedoman Penyusunan dan Penerapan Standar Pelayanan Minimal. Jakarta.

Pemerintah Republik Indonesia. 2006. Peraturan Pemerintah No. 34 Tahun 2006 tentang Jalan. Jakarta.

Planning Commission Government of India. 2010. Manual of Spesification \& Standards: Two-laning of Highways through Public Private Partnership. New Delhi.

United Nations Economic and Social Comission for Asia and the Pacific (UNESCAP). 2003. Road Transport: Formulating ASIAN Highway Network. Bangkok. 